DOI: https://doi.org/10.32839/2304-5809/2020-78.1-3

UDC 82.0:161'2

Gladio Svitlana

Vinnytsia Trade and Economics Institute of Kyiv National University of Trade and Economics

\title{
TENDENCIES AND PATTERNS OF CONTEMPORARY YOUTH SPEECH
}

Summary. The article focuses on defining the general place and functions of unconventional informal language subsystems within the frame of the contemporary language. The subsystems under research - youth jargon and slang - help implement the code of intra-group communication and highlight the idea of belonging to a certain language community. Thus, the aim of the work is to look into the concept of youth speaking habits, study semantic, structural and stylistic features of young people's communication as well as offer an explanation how and with what purpose it is being created at present. It also deals with the ways of extracting ready-made units from other language subsystems; identification a jargon «norm» that spontaneously develops and begins its existence in the form of usus; global tendencies serving as the basis for unification the world teen community; contrast and comparison of English and Ukrainian speaking communities.

Keywords: youth jargon, slang, teen jargon, Ukrainian jargonisms, English jargonisms.

Гладьо C.B.

Вінницький торговельно-економічний інститут Київського національного торговельно-економічного університету

\section{ТЕНДЕНЦІї І МОДЕЛІ СУЧАСНОЇ МОЛОДІЖНОЇ МОВИ}

Анотація. Соціальна стратифікація та полікультурність, технічний прогрес й технологічні революційні інновації, світ гаджетів та панування соціальних мереж, нові «віяння» в культурі комунікації витісняють традиційне спілкування та сприяють розвитку молодіжної мови - жаргону і сленгу, які складають значний прошарок розмовної мови. Саме розмовна мова, як відомо, має тенденцію постійно змінюватися, швидко трансформуватися та безперервно оновлюватися. Молодіжна мова, що поєднуе молодіжний сленг, студентський сленг, молодіжний жаргон, студентський жаргон, жаргон школярів тощо як другорядна форма існування мови характеризуеться специфічним набором лексико-фразеологічних засобів, що відрізняються особливою стилістичною «зніженістю». Мовлення сучасної молоді є не тільки засобом самовираження та визначенням місця комуніканта у мовній спільноті, але й відображуе їі місце у новому технологічному світі, підкреслюючи свою обізнаність, унікальність та приналежність до групи тих, хто «знає і вміє». Ця вербальна підсистема використовуеться людьми певної вікової категорії з метою надання своїй промові експресивності, для найменування актуальних в молодіжному середовищі реалій, які не мають відповідників у літературній мові, а також для забезпечення в умовах внутрішньогрупового спілкування молоді, що протікае в невимушеній, дружній обстановці, комунікативної рівності всіх учасників спілкування. У термінах лінгвопрагматики молодіжний жаргон відзначений значною нестабільністю та локально-темпоральним обмеженням лексико-фразеологічних одиниць, що створюють ядро цієї групи. Ії мінливість простежуеться у безперервній появі нових жаргонізмів і водночас досить швидкому (в межах 5-10 років) «виходу» певної частини одиниць на периферію, а також в переході жаргонних засобів в інші форми існування мови, наприклад, у сленг. Мету статті становить виявлення та систематизація сукупності шляхів створення українських та англійських лексичних одиниць зниженого рівня, а також тенденції відбору вже готових вербальних засобів із суміжних мовних підсистем; вивчення існуючої у вигляді групового узусу норми, що відбиває особливості молодіжного жаргонного слововживання на всіх мовних рівнях, і висвітлення базових функцій молодіжного жаргону.

Ключові слова: молодіжний жаргон, сленг, жаргон підлітків, українські жаргонізми, англійські жаргонізми.

Droblem statement. Contemporary linguis-

1 tics tends to focus on the needs of homo loquens, which partially explains the shift in today's research to unconventional sublanguage systems such as jargon, slang, argo, obscene language and the like. Socially limited forms of speech previously seen as a kind of vagabond language have regained some popularity as a source of vivid expressive means that are not only permissible in informal communication, but are welcome in most respectable circles with the effect of creating a conspiracy atmosphere.

Youth jargon being considered an unconventional form of language existence is traditionally characterized by a specific set of semantic and structural language units distinguished by a special stylistic context; used by a certain age group of people (adolescents and up to 35 year-olds) so as to make their speech expressive and conspicuous. It aims at giving eccentric names to innovations, re-nominating realias relevant to the youth environment that have no names in the literary language. The subsystem under research helps implement the code of intra-group communication and highlight the idea of belonging to a circle of young people who form their own language community. The ever-increasing dynamics of contemporary language development is distinctly reflected in the continuous appearance of new jargonisms, on the one hand, and rather fast (within 5-10 years) obsolescence of a certain part, on the other hand.

Rationale. In terms of pragmatism, functionality and changeability teen jargon tends to be one of the most socially significant formations of jargon which definitely needs further research. It has always been used as a code for adults (mostly parents and teachers) to crack. However, its research is definitely worth the efforts of linguists who constantly attempt to turn "senseless» at first sight teen communication into a comprehensible set of meaning- 
ful and functional phrases. Today's teenagers seem more often than not lost in a meme culture world, which makes them verbalize their thoughts and emotions in text messages or social media posts. This trend has led to "cramming» and "squeezing» rather than describing and explaining, which explicates the domination of unusual acronyms, unfamiliar interjections, and numerous blends in the speech of young people. The marginal and random mixture of verbal signs as a rule makes any grown up doubt their credibility and feel absolutely outdated.

The purpose of the article. The article focuses on a brief survey of jargon studies and aims at analytical comparison of English- and Ukrainian-speaking teen jargon cultures in terms of their semantic, structural, stylistic, pragmatic and functional specifics.

Presentation of the main material. Social diversification implies language variety, heterogeneity of which is determined by at least two factors. The first concerns the territorial differentiation of the language, and the second is related to the division of society into more or less separate social strata, uniting people according to some common social feature (occupation, age, education, etc.). Such social stratification is interwoven into diverse forms of language existence that can be generally divided into primary (literary, mainstream, following the set rules) and secondary ones. The latter comprise language subgroups that highlight linguistic habits of certain social, professional and age groups. For instance, professional sublanguages of doctors, lawyers, IT engineers, lexical subsystems of schoolchildren, students, career novices, argo of criminals and underprivileged people [1, p. 69].

Slang and jargon are two frequently confused language varieties [2]. There exist at least three criteria for their differentiation: 1) type of vocabulary; 2) area of usage; 3) way of usage. Jargon is terminology relevant to a specific activity performed by a certain group of people sharing the same profession. It can often be misunderstood or not understood correctly without a certain context. For instance, from IT jargon: "Вінда" - operational system "Windows"; "знайmu баг" - to find a mistake, "забанити»- to restrict access for the user to a system; to exclude somebody; "деплойнути» to release the application to end users usage.

Slang is a short-term use of colloquial words in the lexicon of people who share the same social or age backgrounds. It is considered non standard and cannot be used in formal situations. Slang as an intermediate form of language existence is positioned somewhat lower than colloquial speech, but above social dialects. The word «хлопець» in Ukrainian has several secondary nominations such as «пацик» (пацан), «шльоцик», "хіляк» (physically weak), «дятел» (dumb) [3, p. 178]. A range of speakers using slang is extremely wide, which brings it closer to the basic forms of language existence, although the difference from them obviously lies in the inability to act as the main form of speech. Generally speaking slang is wider and more informal while jargon is more specific and can be used in a professional context in both written and speaking forms. However, slang and jargon are often used as synonyms.

In language terms jargon being a language subsystem is a result of word games, based on metaphorization of verbal meanings and aimed at creating expressive means with the purpose of imparting figurative speech (in contrast to language subsystems, which perform a conspiratorial function, for example, argo). This kind of nomination leads to the formation of a certain layer of "specific» vocabulary used within this group and often vague to outsiders. For example, students are concerned about academic debts (xвостu), can know something badly (плаватu), cheat (йти на шпорах) and fail the exam (sacunamucb).

Interestingly enough, concise dictionary of contemporary English slang used by students comprises different topics - academic achievement and entertainment of students. For instance, "I can't come to your party, I've got bare work to do." (a lot of, or obviously). "You've finished your dissertation? Jel." (jealous). "Meet me in the libes, I'm on the second floor." (affectionate term for the library). "I've got a tut, but I'm hoping to leave the fac building early to go home for the vac." (tutorial, faculty, vacation) [4].

As young people are more inclined to use jargon than middle-aged and senior people linguists isolate a special group of jargon - youth jargon. Its name highlights age as the main criterion for determining its social status. Traditionally users of youth jargon range from 10-13 to 35 years. Social (as well as age) heterogeneity of the group results in the mixture of slang, criminal argo, professional and corporate jargons presented in the speech of young people. Thus, it is commonly accepted that youth jargon is not a homogeneous formation, but rather has the core of general youth jargonisms and the periphery represented by verbal units of a transitional nature (professional and group jargon, criminal vocabulary, taboo and obscene words, dysphemisms et. al.). The age variety calls for further subdivision of youth jargon into school jargon (10-18 year-olds); student jargon (18-25 year olds) and speech of young adults (26 to 35 years old). The core of the two latter groups includes a mixture of youth slang and professional jargon that can be recognized by all three subgroups. For example, Пичалька, Узпагойся, ОМГ, ХЗ, Ykwtfgo (You Know What The $F^{* * *} k$ is going on), Lit (to express something awesome) and others [5].

Another distinguishing feature of youth jargon is the mobility of its components and rapid (within 5-10 years) interchangeability of a significant part of its units. Therefore, jargonisms denoting certain realia are gradually subject to obsolescence and oblivion, for example, names of items of clothing that have gone out of fashion ("safari dress", "hedgehog", "feathers", "spikes" (types of hairstyles for punks), dances "break-dance", "gingham style». However, they have become temporal symbols, markers of a certain time period instead.

At the same time, jargonisms naming universal objects, actions, conditions, etc., while becoming outdated go to the periphery of active use, but are not forgotten completely (compare the long-lasting usage of such words as "dude", "bucks", "chicks", etc.). Over the past decades, jargon has consistently developed new names for the concept of money "bacon", "cheddar", "cabbage", "cash", adding to the existing list new names [6]. All of them are used to this day, however, with varying degrees of activity and diverse implications. 
The final issue that is going to be considered in the article is the concept of slang norm. Being a non-coded subsystem, it develops spontaneously and is implemented in the form of usus, which, in its turn, allows significant variability in the implementation of certain means at the phonetic, morphological, and syntactic levels. For instance, «лейба», "лейбл», "лейбак" (a label on clothes, etc.); periodt (a word used at the end of a sentence, meant to add emphasis to a point that has been made. It is often regarded as a more extreme or intense version of "period." A comma separates "period" from the rest of the sentence. It also sometimes seen as "periot" [4].

Still, an obvious violation of the jargon norm by a person who does not know this jargon is momentarily noticed by jargon users and, thus, jargon serves as a password, as a kind of identification. Ambiguity and semantic heterogeneity of jargonisms can result in the distortion of their meanings, used in an unusual context. For instance, "Bet" is a word that has many uses. It can be used in lieu of the word "OK" or "YES," but it can also be used as a response when someone challenges you, instead of saying "watch" or "we'll see" [Ibid.].
Frequently such distortion occurs while a word suffers transition from one language to the other and back. For example, a well-known farewell phrase "take care» was translated into Ukrainian as «Бережи себе», which in fact means "have a nice day". The English adjective «bad» (поганий) дав початок жаргонізму «набедитu» (to make some trouble) [3, 194-195], which in its turn can be translated as "to mess up".

Conclusion. Social stratification of the language is found in the form of variability of the language system, leading to the formation and coexistence of various forms of language. The forms of existence of the language are divided into main (literary language, colloquial speech, territorial dialects) and secondary (argo, professional sublanguages, group jargons, slang). As an intermediate between the main and secondary forms of the existence of the language, the currently forming subsystem - slang - is singled out.

Youth jargon is a secondary, functionally complementary form of the existence of a language, which has a spontaneously developing norm that exists in the form of usus, reflecting its phonetic, lexical, morphological features, as well as regulating the organization of jargon in the text.

\section{References:}

1. Bondaletov V. (1987). Sotsialnaya lingvistika [Social linguistics]. Moskva: Prosveshchenije.

2. Orlova N. (2004). Sleng vs zhargon: Problema definitsii [Slang vs Jargon: The Problem of Definition]. Yaroslavl Pedagogical Bulletin, no 3. URL: http://vestnik.yspu.org/releases/novye_Issledovaniy/24_6/

3. Ponomarev O. (2000). Stylistyka suchasnoi ukrainskoi movy [Stylistics of the Modern Ukrainian Language]. Ternopil: Navchalna knyha.

4. A very concise dictionary of student slang. URL: https://www.theguardian.com/education/2012/sep/18/concisedictionary-of-student-slang

5. Slang Word List. URL: https://slangwordlist.com/new-teen-slang/

6. 80+ Slang Words for Money: List of Slang Terms for Money. URL: https://writingexplained.org/slang-for-money

\section{Список літератури:}

1. Бондалетов В.Д. Социальная лингвистика. Москва : Просвещение, 1987. 159 с.

2. Орлова Н.О. Сленг vs жаргон: Проблема дефиниции. Ярославский педагогический вестник. 2004 . № 3. URL: http://vestnik.yspu.org/releases/novye_Issledovaniy/24_6/

3. Пономарів О.Д. Стилістика сучасної української мови. Тернопіль : Навчальна книга, 2000. 248 с.

4. A very concise dictionary of student slang. URL: https://www.theguardian.com/education/2012/sep/18/concisedictionary-of-student-slang

5. Slang Word List. URL: https://slangwordlist.com/new-teen-slang/

6. 80+ Slang Words for Money: List of Slang Terms for Money. URL: https://writingexplained.org/slang-for-money 